\title{
Analyzing students' abstraction in learning common tangent lines of two circles based on cognitive styles
}

\author{
Wirani Sumekar, Farida Nurhasanah, Sutopo ${ }^{1}$
}

\begin{abstract}
Abstrak: Penelitian kualitatif ini bertujuan untuk mendeskripsikan abstraksi siswa SMP dengan gaya kognitif berbeda dalam mempelajari garis singgung pada dua lingkaran yang dianalisis menggunakan model RBC (Recognizing, Building-with, Construction). Data penelitian dikumpulkan melalui angket, tes tertulis, dan wawancara berbasis tugas. Delapan siswa dengan gaya kognitif field-dependent dan field-independent dipilih sebagai subjek penelitian. Data penelitian dianalisis berdasarkan rekaman wawancara yang sudah ditranskrip dan dikelompokkan berdasarkan tindakan kognitif model RBC. Hasil penelitian menunjukkan bahwa siswa field-dependent cenderung memerlukan petunjuk dan waktu lebih lama untuk mengenali dan membangun konsep garis singgung pada dua lingkaran melalui pengetahuan terdahulu hingga sampai pada aktivitas konstruksi. Sementara siswa field-independent cenderung langsung mengenali dan membangun konsep garis singgung pada dua lingkaran melalui pengetahuan terdahulu sehingga berhasil mengkonstruksi konsep garis singgung pada dua lingkaran. Penelitian ini menunjukkan bahwa (1) siswa field-dependent lebih sedikit menggunakan pengetahuan terdahulu yang berkaitan dengan konsep garis singgung dua lingkaran daripada siswa field-independent yang cenderung dapat melihat sebagian besar pengetahuan lama yang relevan dengan konsep garis singgung dua lingkaran, (2) siswa dengan gaya kognitif yang sama belum tentu menunjukkan keberhasilan yang sama pada proses abstraksi.
\end{abstract}

\section{Kata kunci: Abstraksi, Dua lingkaran, Garis singgung, Gaya kognitif, Model RBC}

\begin{abstract}
This study was aimed to describe the abstraction process of students with different cognitive styles in learning common tangent lines of two circles using recognizing, buildingwith, and construction (RBC) model. This qualitative research collected data through questionnaires, written tests, and task-based interviews. Eight students with field-dependent and field-independent were involved as the subjects. The interview transcripts were analyzed and grouped into cognitive actions of the RBC model. Findings showed that to reach the stage of construction activities, field-dependent students tend to need guidance and more time in recognizing and constructing the concept of a common tangent of two circles using their prior knowledge. Meanwhile, field-independent students tend to directly recognize and construct the concept using their prior knowledge so that they successfully constructed the concept of common tangent lines of two circles. This study shows that (1) field-dependent students use their prior knowledge that relates to the concept of common tangent lines of two circles less than field-independent students who tend to be able to use most of their prior knowledge relevant to the concept of common tangent lines of two circles, and (2) students who has similar cognitive style may not show the same success in abstraction process.
\end{abstract}

Keywords: Abstraction, Circles, Common tangent line, Cognitive style, RBC Model

\footnotetext{
${ }^{1}$ Department of Mathematics Education Universitas Sebelas Maret Surakarta, Jl. Ir. Sutami No.36 A, Kota Surakarta 57126, Indonesia, nurhasanahfarida@gmail.com
} 


\section{A. Introduction}

Mathematics has an abstract object of study. For example, its abstractness can be found in the concept of triangles and linear equations. The concepts in mathematics are constructed from previous concepts (Soedjadi, 2000). Shadiq (2009) argues that the students should construct new concepts independently in learning mathematics which is built on the existing concepts in their scheme. The formation of a new concept is called abstraction (Nurhasanah, Kusumah, \& Sabandar, 2013). Ferrari (2003) asserts that abstraction is a fundamental process in mathematics. The abstraction in the process of learning mathematics is inevitable since it plays paramount roles in the formation of mathematical concepts. Thus, the activities involving the process of abstraction is needed as it helps the students construct new concepts appropriately through the concepts they already have in order to make a connection.

Hershkowitz, Schwarz, and Dreyfus (2001) define abstraction as an activity in which students vertically reorganize mathematical structures previously constructed into new mathematical structures. They argue that actions in the process of abstraction tend to be mental actions that cannot be directly observed. In this case, they provided a methodological framework for analyzing students' abstraction through three epistemic actions. Epistemic actions are mental actions that can be observed through verbal actions or physical actions taken by students. The identification of epistemic actions relevant to the abstraction process is Recognizing, Buildingwith, and Construction or known as the RBC Model.

In RBC model, recognizing occurs when students realize that prior knowledge is attached to a given mathematical situation (Tsamir \& Dreyfus, 2002; Hershkowitz et al., 2007; Dreyfus, Hershkowitz, \& Schwarz, 2015; Celebioglu \&Yazgan, 2015; Memnun et al., 2017). With regard to the action, recognizing involves trying to compare the results of the previous action and stating that the structure is similar or suitable. Building-with is the activity of combining existing knowledge to meet objectives, for example, to solve problems or prove the truth of a statement (Tsamir \& Dreyfus, 2002; Hershkowitz et al., 2007; Dreyfus et al., 2015; Celebioglu \&Yazgan, 2015; Memnun et al., 2017). Thus, the same task can be developed by one student, but constructed by another student, depending on the student's personal history (Tsamir \& Dreyfus, 2002). Construction is the main step of abstraction (Tsamir \& Dreyfus, 2002; Hershkowitz et al., 2007; Dreyfus et al., 2015). This action consists of gathering all the knowledge artifacts to produce a new knowledge structure. In a building-with structure, the goal is achieved by using the knowledge that has been recognized before, while in the construction structure, construction and restructuring of knowledge is the goal of the activity (Tsamir \& Dreyfus, 2002).

At the secondary school level, geometry is a branch of mathematics that studies the properties, measurements, and relationships of points, lines, fields, and space (NCTM, 2000). In the Indonesian school context, geometry is problematic mathematics topics since a large number of students had difficulties in connecting and identifying mathematical ideas to find solutions to problems of the triangles (Agnesya, 2015). Mutia (2017) found that many students have difficulties in understanding the concept of solid geometry plane surfaces. This shows that students' understanding of abstract ideas or concepts in mathematics, especially geometry is still under-achieved.

The way students construct abstract concepts varies. Susanto (2008) explains that the learning process is influenced by individual characteristics, for example, cognitive style. Mayer and Massa (2003) assert that cognitive style delineates how students process and represent information. Prior studies (e.g., Tinajero \& Paramo, 1998; Alamolhodaei, 2001; Pitta-Pantazi \& 
Christou, 2009; Chrysostomou et al, 2013; Nurafni, Miatun, \& Khusna, 2018) have revealed that cognitive styles contribute to students' performance in mathematics. Some authors (Witkin et al, 1977; Marashi \& Moghadam, 2014; Onwumere \& Reid, 2014) categorize cognitive style into field-dependent (FD) and field-independent (FI). These cognitive styles reflect the presence or absence of the nature of dependence on the environment so that the way students process information allows the emergence of differences or obstacles in the process of abstraction when learning geometry activities both in the stages that are able to be reached and the way students express ideas.

Many studies have revealed abstractions using RBC models with different subjects (Dreyfus, 2007; Memnun et al., 2017; Hassan \& Mitchelmore, 2006; Celebioglu \& Yazgan, 2015; Katranci \& Altun, 2013) but researchers have not found any research that revealed students' abstraction in constructing new knowledge based on cognitive style of students. Considering the importance of abstraction in learning mathematics (e.g., Hershkowitz et al., 2002; Ferrari, 2003), students' difficulties in geometry (Gal \& Linchevski, 2010; Mutia, 2017), and the roles played by cognitive style in learning mathematics (Mayer \& Massa, 2003; Chrysostomou et al., 2013), the present study aims to reveals the students' abstraction in learning common tangent lines of two circles based on their cognitive style. Besides enriching our knowledge on students' abstraction, this research contributes to mathematics teachers' understanding of how students, based on their cognitive styles, utilize prior knowledge to construct new knowledge.

\section{B. Methods}

The present study employs a qualitative approach (Moleong, 2007). Eight of 32 seventhgrade students were selected as the subjects based on three criteria. First, students had FI and FD cognitive styles as a result of the questionnaire. Second, students showed abstraction activities during group work. Third, students answered all the questions given in the task completely. Every four subjects are respectively, FD and FI students.

Data in this study was collected through task-based interview, test, and questionnaire. The questionnaire, Group Embedded Figure Test (GEFT), adopted from Witkin et al. (1977), was used to collect data on students' cognitive styles. It is a standardized test with a reliability index of 0.820 (Witkin, in Bostic, 1988). This instrument has been widely used by the researchers (e.g., Yuen, 2015) for analyzing cognitive style. The abstraction test, which consists of two questions (Table 1), was used as a basis for the interview to examine students' abstraction. The first question aims to help students distinguish the type and the properties of common tangent lines of two circles. Meanwhile, the second question supports the students to determine the length and the difference of the type of common tangent lines of two circles. The subjects were grouped in four; each group consisted of two subjects with similar cognitive styles (Table 3). The purpose of grouping was to see the abstraction that arises when interacting with their partners. The abstraction that arises during group activities as the main consideration in choosing a subject.

The interview was conducted individually based on the results of the abstraction test. During the interview, the researchers played a role as participant observers. The students' process when taking the test and interview was recorded with a video camera to prevent forgetting the situations in which the interviews were being conducted and allow the researchers to review it as often as wanted. The video recording was verbatim-transcribed. The transcripts were analyzed and grouped based on three abstraction activities in the RBC model. The indicators of abstraction 
were made by referring to abstraction activities according to Hong and Kim (2015) and Memnun et al. (2017) as presented in Table 2. The interviews were conducted twice to verify that the data obtained was credible. The external validity was provided with reporting in detail what has been done so the readers can trace and guide other researchers in determining their data when carrying out similar studies (Sugiyono, 2015).

Table 1. Task on the abstraction test

\begin{tabular}{cc}
\hline No. & \multicolumn{1}{c}{ Problems } \\
\hline 1 & A line tangent to two circles with the centre of circles is $\mathrm{M}$ and $\mathrm{N}$. \\
& a. If the centres of the two circles are connected together, create as \\
many illustrations as possible to illustrate the condition and \\
determine which lines are perpendicular to the illustration you \\
made in the column below! \\
b. Based on the illustrations you made, what did you find? Give a \\
short explanation! \\
Double-check your answers in the number 1! Can you determine the \\
length of the tangents for each illustration you make if any radius of \\
each circle and the distance between the two centre points of the \\
circle are known? If so, how long and how? If not, give your reason!
\end{tabular}

Table 2. Students' abstraction indicators in learning common tangent lines of two circles

\begin{tabular}{|c|c|c|c|}
\hline No. & Action & Definition & Examples \\
\hline 1 & Recognizing & $\begin{array}{l}\text { Students recognize the } \\
\text { previous knowledge which } \\
\text { relevant to the given } \\
\text { situation }\end{array}$ & $\begin{array}{l}\text { - Recognizing to use the relative } \\
\text { position of two circles } \\
\text { - Recognizing to use properties of a } \\
\text { circle } \\
\text { - Recognizing to use the Pythagorean } \\
\text { theorem }\end{array}$ \\
\hline 2 & Building-with & $\begin{array}{l}\text { Students can associate } \\
\text { mathematical } \\
\text { characteristics/knowledge/ } \\
\text { structures with the given } \\
\text { problems }\end{array}$ & $\begin{array}{l}\text { - Using the concept of a tangent line } \\
\text { to a circle to solve the first and } \\
\text { second question } \\
\text { - Using knowledge of the distance } \\
\text { between two points to solve the } \\
\text { second question }\end{array}$ \\
\hline 3 & Construction & $\begin{array}{l}\text { Students identify the } \\
\text { characteristics of the } \\
\text { knowledge formed }\end{array}$ & $\begin{array}{l}\text { - Constructing the definition of } \\
\text { common tangent lines of two circles } \\
\text { - Constructing the length of external } \\
\text { and internal common tangent lines } \\
\text { of two circles }\end{array}$ \\
\hline
\end{tabular}

\section{Findings and Discussion}

In this part, we present the students' processes of constructing the concept of common tangent lines of two circles which refer to three epistemic actions. The subjects in this study are coded as in Table 3. 
Table 3. Students' group based on their cognitive style

\begin{tabular}{ccc}
\hline Groups & Students & Cognitive Style \\
\hline Group 1 & SD-1, SD-2 & Field-dependent \\
Group 2 & SD-3, SD-4 & Field-dependent \\
Group 3 & SI-1, SI-2 & Field-independent \\
Group 4 & SI-3, SI-4 & Field-independent \\
\hline
\end{tabular}

\section{The abstraction of field-dependent students}

The FD students' work on the tasks can be seen in Figure 1 and Figure 2. The figures show the differences in FD students' answer. In Figure 1, group 1 made six illustrations showing the possible common tangent lines of two circles by considering the position of the two circles and the number of common tangent lines they have on each illustration. In Figure 2, group 2 made three illustrations displaying the possible common tangent lines of two circles.

In recognizing action, the processes occurred on SD-1 and SD-2 are almost the same. They both recognized the concept of a tangent to a circle and the relative position of two circles to construct definitions of common tangent lines of two circles. However, in some cases, SD-1 required more time and instructions than SD-2 such as recognizing properties of a circle when two circles with equal radii and two circles with different radii have different effects on the properties of common tangent lines of two circles. It made SD-1 unable to sort out specific prior knowledge relating to the problem. Both SD-1 and SD-2 recognized the knowledge that has been obtained in the previous activity and applied it in the next activity. For instance, the activity was given to determine the procedure to find the lengths of common tangent lines of two circles, the subjects considered prior knowledge about the Pythagorean theorem.

In the same action, SD-3 and SD-4 underwent a similar process but tended to be incomplete. In constructing the definition of common tangent lines of two circles, the two subjects recognized the concept of tangents to a circle and the relative position of two circles but could not show the type of position of two circles completely. However, SD-4 recognized prior knowledge directly by himself rather than SD-3 who needed some questions in obtaining clues about prior knowledge existing in the new situations given. In constructing the properties of common tangent lines of two circles, the process occurred on SD-3, and SD-4 is the same in recognizing prior knowledge in the given situation, namely requires assistance in the form of questions that are expected to help the subjects in finding the clues. Furthermore, before the questions were given, both subjects did not realize that the task in the situation related to their prior knowledge. In constructing the length of common tangent lines of two circle, both SD-3 and SD-4 recognized the construction of prior knowledge about parallel lines on two circles that have the same radius but cannot find compatibility when applied to two circles with different radii.

In building-with action, the process occurred in the subjects of group 1 and group 2 tend to be different. Those four subjects processed information that had been identified previously by linking it to the new situation given so as to get a solution. However, the subjects in group 1 could solve it easier and more complete. They could explain the relationship between information than two subjects in group 2. Another difference is that two subjects in group 1 needed less assistance in processing information than two subjects in group 2 who had difficulty in associating and processing information that they recognized even though they were both given instructions. 


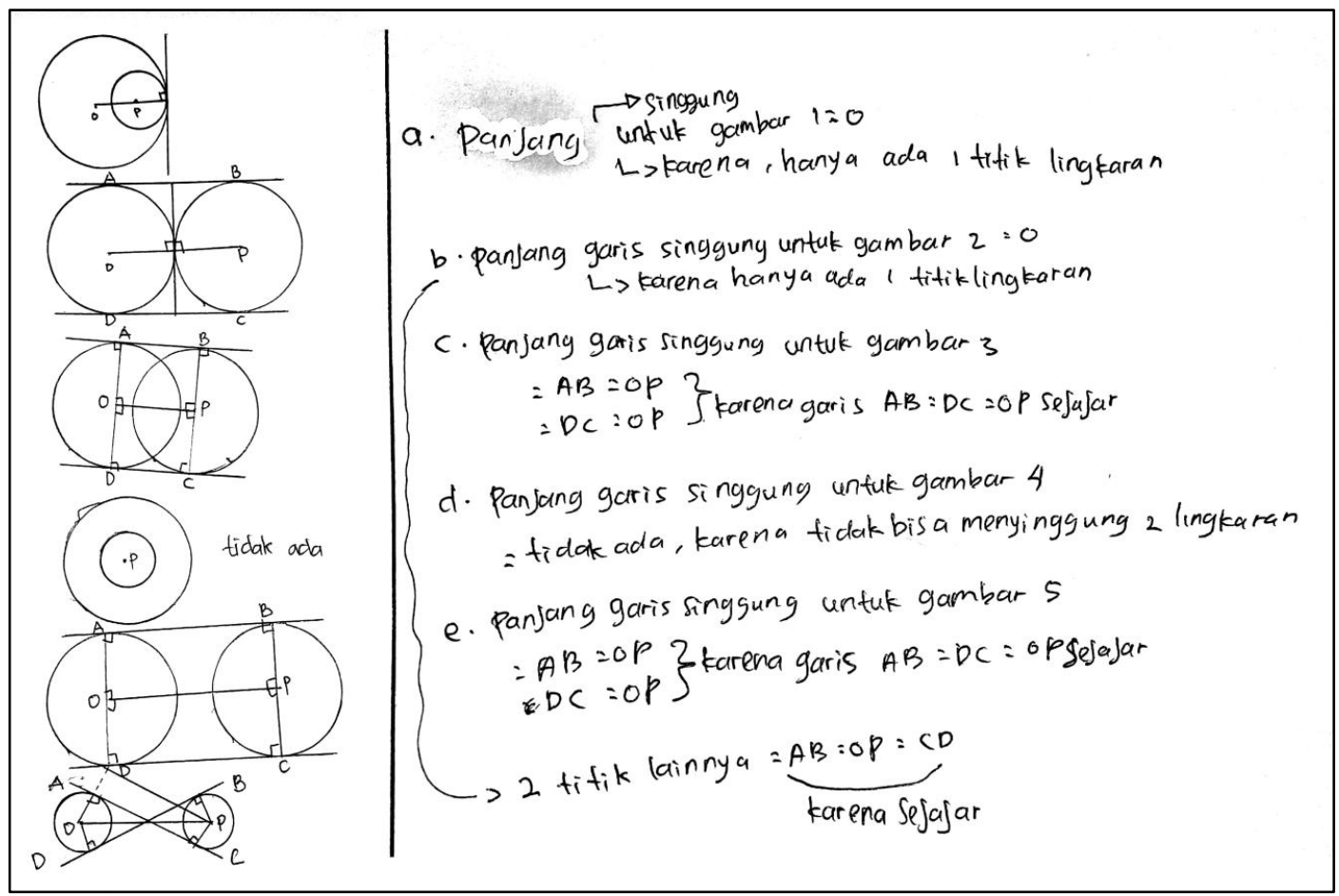

Figure 1. Students' works in group 1
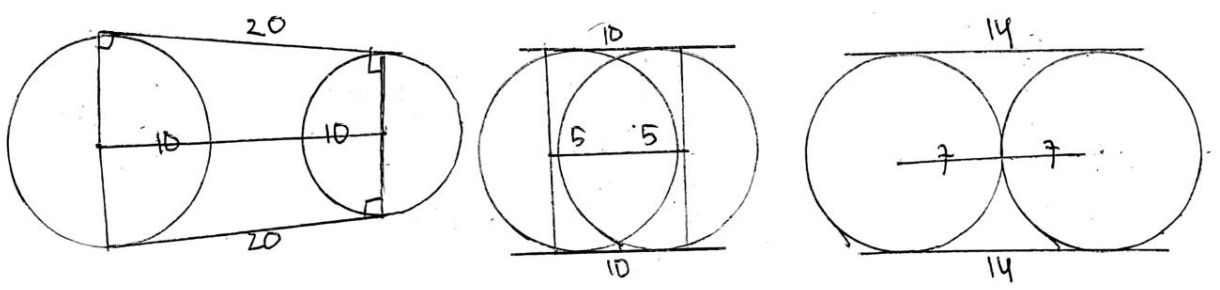

Figure 2. Students' works in group 2

In construction action, there were differences between the two groups in constructing new knowledge. SD-1 and SD-2 constructed new knowledge by classifying two types of common tangent lines of two circles and two formulas to determine the length of common tangent lines of two circles, showing ones as a sample illustration of common tangent lines of two circles and another which is not, and finding the general properties of common tangent lines of two circles. SD-3 and SD-4 had not succeeded in constructing new knowledge even though it had been given some follow-up questions expected to guide them in finding ideas as indicated by $\left[\mathrm{P}_{\mathrm{I}, 125}\right]$ to $\left[\mathrm{P}_{\mathrm{I}, 129}\right]$. The following is a dialogue during an interview with SD-4.

$P_{I, 125} \quad: \quad$ Now, for example, this tangent point (pointing to the tangent point of the big circle at scratch 18) is a point outside the circle. If the circle does not exist. It is just a point, right at the point of contact. Then you are asked to determine the length of the tangent line, the length of the tangent line to the point outside the circle. It is the same as you learn the tangent to a circle in the previous. Can you find the length? 


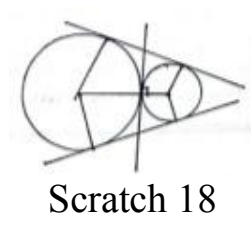

$\begin{array}{ll}S D-4_{I, 125} & : \text { Of course. } \\ P_{I, 126} & : \text { How is it going? } \\ S D-4_{I, 126} & : \text { By using Pythagoras } \\ P_{I, 127} & : \text { Pythagoras is used for right triangles, isn't it? } \\ S D-4_{I, 127} & : \text { Yes. } \\ P_{I, 128} & : \text { Where are the angles? } \\ S D-4_{I, 128} & : \text { Mmm ... right here (pointed out the tangent to a circle) } \\ P_{I, 129} & : \text { It is perpendicular, isn't it? } \\ S D-4_{I, 129} & : \text { Actually not. Both of the circles are not (pointing at the two circles). } \\ & : \text { Do you think they are perpendicular? I don't think so } \\ P_{I, 136} & : \text { Then, what are you going to do to find the length of the tangent? } \\ S D-4_{I, 136} & : \text { Mmm...I don't know. }\end{array}$

The dialogue above shows that SD-4 fails to construct the properties of common tangent lines of two circles. This failure impedes further activity in constructing the length of common tangent lines of two circles as indicated by $\left[\mathrm{SD}-4_{\mathrm{I}}, 136\right]$. On the other hand, SD-1 and SD-2 were successful in construction activities. However, there were differences between the two. SD-2 could easily identify the characteristics of new knowledge than SD-1. SD-1 needed clues to find the characteristics of the knowledge acquired even though they both required a long time.

\section{The abstraction of field-independent students}

FI students' works are presented in Figure 3 and Figure 4. In Figure 3, group 3 made four illustrations showing the possible common tangent lines of two circles based on the relative position of the two circles, the properties of a circle, and the number of tangents they had in each illustration. They also considered the concept of equality of ratio numbers in the second problem. In Figure 4, group 4 made five illustrations exhibiting the possible tangents of the two circles by considering the relative position of the two circles, the properties of a circle, and the number of tangents they had on each illustration. These show the differences in FI students' answers.

In recognizing action, SI-1, SI-2, SI-3, and SI-4 tend to do the same thing. They recognized prior knowledge related to new situations in the given task, such as the concept of a tangent to a circle, the relative position of two circles, and properties of a circle to construct the definition of common tangent lines of two circles. They also recognized prior knowledge about parallel and perpendicular line to construct properties of common tangent lines of two circle. Based on the interviews, the four subjects could easily recognize the definition and properties of common tangent lines of two circles obtained in the previous activity and applied it to determine the length of common tangent lines of two circle so as to form new knowledge as a whole. However, SI-1 and SI-2 needed some guidance to realize that previous knowledge they mentioned, namely Pythagorean theorem needed to be considered in constructing length of common tangent lines of two circles. SI-1 also did not fully recognize that Pythagorean theorem is relevant to the task given although he could mention it when given direct questions by the researcher in $\left[\mathrm{P}_{\mathrm{I}, 198}\right]$ as shown in the following dialogue. 
a.

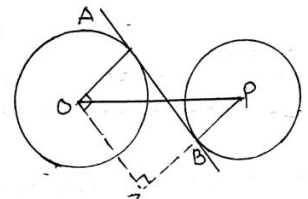

b.

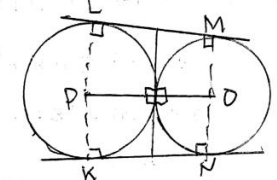

c.
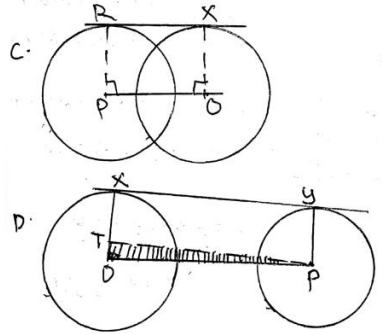

$1: 8$

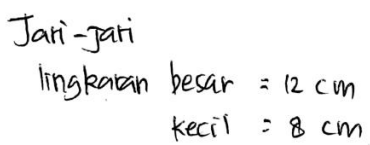

1) Jarak titik pusat $=40 \mathrm{~cm}$ panjang garis singsung $=33 \mathrm{~cm}$

2) Jarak titik pusat $=20 \mathrm{~cm}$ pavijang $=19 \mathrm{~cm}$

3) Jarak titik pusat $=12 \mathrm{~cm}$ Jari-Jari $=8 \mathrm{~cm}$ panjang $=12 \mathrm{~cm}$

4) Jarak tifik pusat $=40 \mathrm{~cm}$ panjans $=39 \mathrm{~cm}$

Figure 3. Students' works in group 3
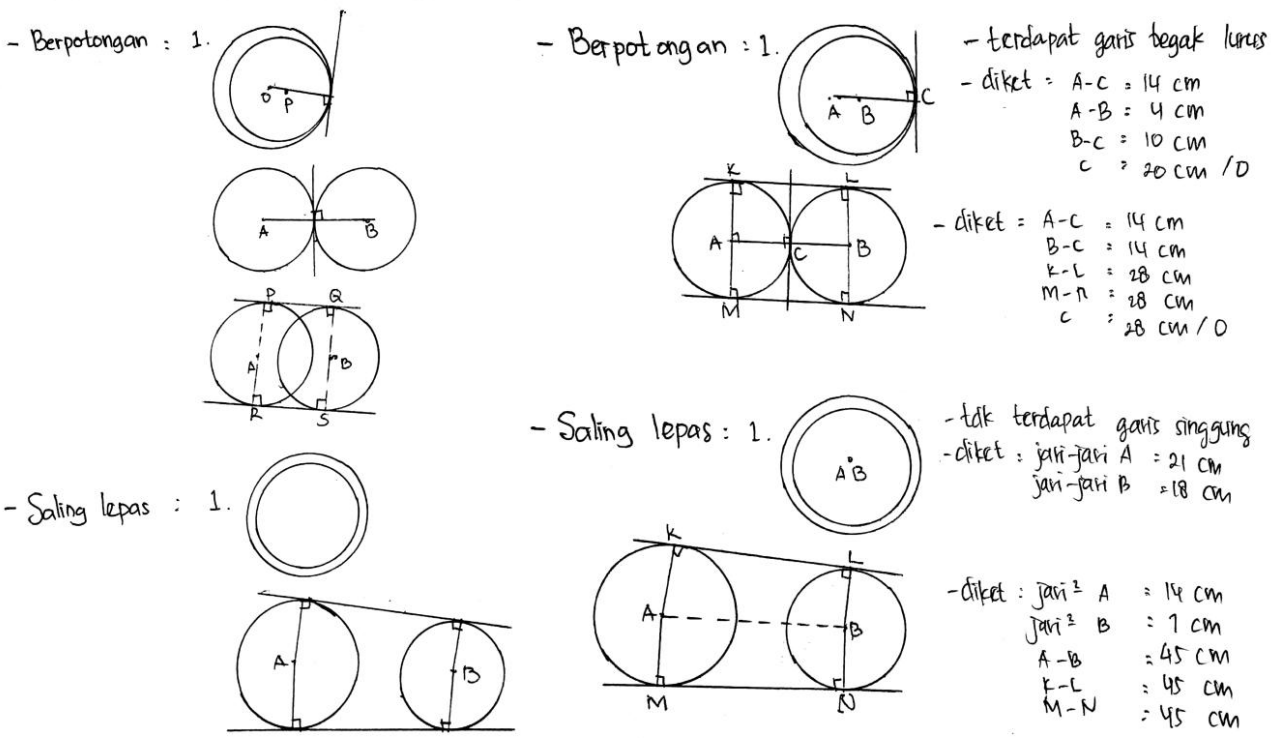

- tak terdapat gavis singgung

- diket : jari-jari $A=21 \mathrm{~cm}$ $\begin{array}{rl}\text { jari-jari } B=18 \mathrm{Cm} & \mathrm{Cm}\end{array}$

Figure 4. Students' works in group 4
SI-1 $1_{I, 166} \quad:$ We can use ratio, can't we?
$P_{I, 167} \quad:$ What kind of proportion?
SI-1 $1_{1,167} \quad:$ Equality of ratio number.
$P_{I, 198} \quad:$ Hmm... use ratio? Okay. Mmm ... do you still remember the triangle topic in the $1^{\text {st }}$ semester? Or, do you still remember how to find the length of the tangent in a circle?
SI-1 $1_{1,198} \quad:$ As yet
$P_{I, 199} \quad:$ How do you find the length?
SI- $1_{I, 199}$ : Make the circle first, don't we?
$P_{I, 200} \quad:$ All right. You may use the reverse sheet if you need more space
SI-1 $1_{I, 200} \quad: \quad$ Sure (make a scratch 12) Like this one? 


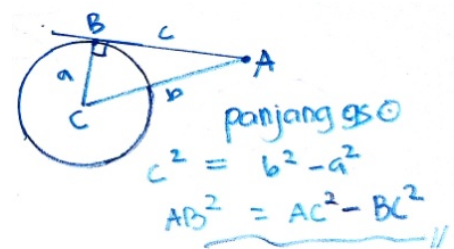

$$
\begin{aligned}
& P_{I, 201} \quad: \text { What did you use? } \\
& \text { SI-1 }_{I, 201}: \text { Pythagoras }
\end{aligned}
$$

Scratch 12

The dialogue above shows that SI- 1 could remember the knowledge stated by [SI- $1_{\text {I, }} 198$ ], $\left[S I-1_{I}, 200\right]$, and $\left[S I-1_{I}, 201\right]$. However, he did not realize that he still needed to complete the given tasks that relevant to his knowledge of the Pythagorean theorem in problem number 2 so he couldn't solve it. Additionally, SI-1 recognized prior knowledge that was not taken into consideration, as stated by $\left[\mathrm{SI}-1_{\mathrm{I}}, 166\right]$ and $\left[\mathrm{SI}-1_{\mathrm{I}}, 167\right]$. Similar to SI-1, SI-2 also recognized the prior knowledge that was not taken into consideration by other subjects [SI-2 I, 128], but then he realized that such knowledge has no strong connection with the problem when given help with some further questions. The assistance in the form of questions is shown by $\left[\mathrm{P}_{\mathrm{I}}, 138\right]$ through $\left[\mathrm{P}_{\mathrm{I}}\right.$, 144].
$P_{I, 127} \quad:$ How do you find the tangent length of each illustration?
SI-2 $2_{1,127}:$ We can use any methods, can't we?
$P_{I, 128} \quad:$ Use the method you have already know.
SI-2I,128 : Using a direct proportion. A scale of one to eight.
$P_{I, 138} \quad:$ Take a look, what line is this (pointing at OC on scratch 13)? How's the position?

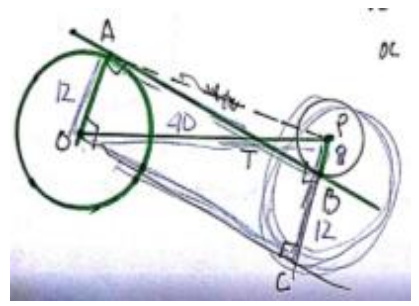

Scratch 13

SI-2 ${ }_{I, 138} \quad$ : This (pointing OC line) is parallel to tangent line AB (pointing tangent line $A B$ )

$P_{I, 139} \quad:$ What about this one (pointing to the $B C$ line)?

SI-2I,139 : It's parallel (pointing at the OA line)

$P_{I, 140} \quad:$ If there are two pairs of parallel lines meeting at this point (point to $\operatorname{dot} A, B, C$, and $O)$. How is the result?

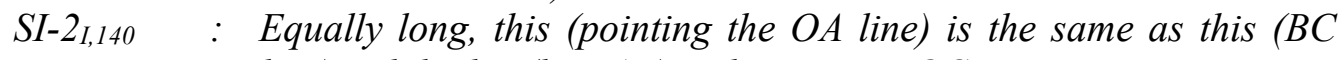
line). While this (line $A B$ ) is the same as $O C$

$P_{I, 141} \quad:$ If $O A$ is the same as $B C$, can you solve the PC?

SI-2I,141 : Of course.

$P_{I, 142} \quad:$ How is it going?

SI-2I,142 : Twelve plus eight equals to $20 \mathrm{~cm}$

$P_{I, 143} \quad:$ Well, is there any OP?

$S I-2_{I, 143}:$ Yes, $40 \mathrm{~cm}$

$P_{I, 144} \quad:$ Can you find OC?

SI-2 ${ }_{I, 144} \quad:$ Yes, we can use Pythagoras.

$P_{I, 145} \quad:$ How is it going? 
SI-2I,145 : This (pointing to the OA line) is the same as this (line BC) because it is parallel. Thus, the $P C$ is $20 \mathrm{~cm}, O P$ is equal to $40 \mathrm{~cm}$, so this (pointing at the $O C$ ) is parallel to the tangent line (pointing to the line $A B)$, this length (OC line) can be solved by using the Pythagorean theorem

$P_{I, 146} \quad:$ How is it going?

SI-2I,146 : OC squared is equal to OP squared minus $P C$ squared

$P_{I, 147} \quad:$ Just finish it.

SI-2 ${ }_{1,147} \quad$ : (making scratch 14) What do I do to the coma, Ma'am?

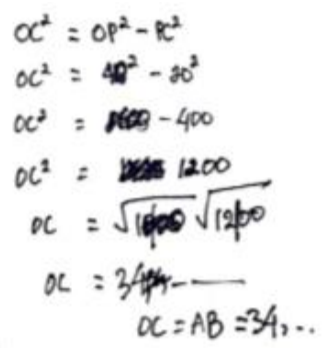

Scratch 14

In building-with action, SI-1 was different from the other three in constructing the length of common tangent lines of two circle. SI-1, using a concept of ratio number, linked the existing information without using the prior knowledge that related to the task, while the other three subjects related to previous knowledge relevant to the task at hand. It was possible since SI-1 had not yet realized that there was prior knowledge needed to be able to link all information so as to solve the tasks correctly. SI-2 applied a different focus from SI-3 and SI-4 in connecting knowledge to the situation. SI-2 connected his knowledge by manipulating the object he saw so that the situation encountered was the same as the construction of prior knowledge as indicated by $\left[\mathrm{SI}-2_{\mathrm{I}, 107}\right]$ and $\left[\mathrm{SI}-2_{\mathrm{I}}, 112\right]$, while SI-3 and SI-4 applied the existing knowledge to the situation.

$P_{I, 112} \quad:$ Why did you make this line (point to the OC line on scratch 13)?

SI-2I,112 : It is the same as this (pointing at scratch 7), for example, $B$ the centre of the circle with the radius of $B C$ is the same as $O A$, so $C$ is perpendicular

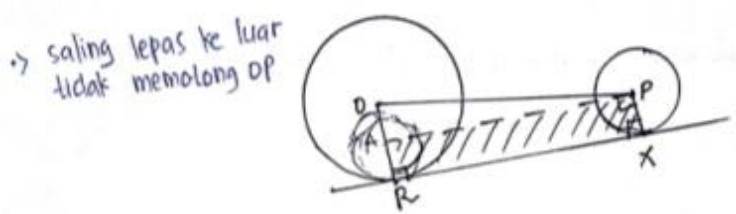

Scratch 7

Below is the dialogue with SI-4 in building-with action.

SI-4I,95 : (creating scratch 11) Done. 


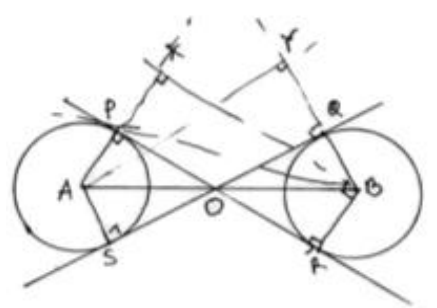

Scratch 11

\begin{tabular}{|c|c|}
\hline$P_{I, 96}$ & Give the dot name. \\
\hline$S I-4_{I, 96}$ & (giving the dote name) Finish. \\
\hline$P_{I, 97}$ & Then, how is it going? \\
\hline$S I-4 I, 97$ & $\begin{array}{l}P \text { is perpendicular as the tangent is also perpendicular to radius } A \text {, } \\
\text { circle } A, B R \text { radius, make this } P X \text { line (pointing to line } P X) \text { parallel } \\
\text { to } B R \text { (pointing to line } B R \text { ) } B X \text { (pointing to line } B X \text { ) with length } P R \text {, } \\
\text { parallel (pointing lines } B X \text { and } P R), P \text { is perpendicular } X \text { is also } \\
\text { perpendicular. This is (pointing to PRBX flat) rectangle. } R \text { is } \\
\text { perpendicular. After this (pointing at the } Q Y \text { line) parallel to the } \\
\text { radius (pointing at the US line), rectangular (pointing at } Q Y A S \text { ), and } \\
\text { perpendicular (pointing at } S \text { and } Q \text { ) }\end{array}$ \\
\hline$P_{I, 98}$ & $\begin{array}{l}\text { Why did you make a parallel line to the radius? This parallel } \\
\text { (tangent) too? }\end{array}$ \\
\hline$S I-4_{I, 98}$ & $\begin{array}{l}\text { Because...tangent of a circle is perpendicular to the radius or } \\
\text { diameter. This is the radius (pointing to } A P, U S, B Q \text {, and BR lines). } \\
\text { This is perpendicular (pointing } P, Q, R, S) \text {. The lines are slanted } \\
\text { (pointing PR lines). While this is a triangle (pointing to an APO } \\
\text { triangle), this should be a right triangle. }\end{array}$ \\
\hline
\end{tabular}

In construction action, there was a difference between SI-1 and other three subjects. SI-2, SI-3, and SI-4 could directly identify the characteristics of knowledge acquired so as to form new knowledge, whereas SI-1 was not successful in constructing new knowledge. This difference was possible since SI-1 had not succeeded in constructing prior knowledge. SI-2, SI3 , and SI-4 identified the characteristics of the knowledge acquired so that they could classify two types and formulas of common tangent lines of two circle, show ones as examples and not examples, and find the general properties common tangent lines of two circles. Even they were well-succeeded in constructing new knowledge, SI-3 and SI-4 experienced an error when making a formula applied to the new knowledge obtained. The error was realized when both subjects were given a number of questions that needed to be corrected.

The four FD subjects tend to be the same in the process of doing abstractions, that is requiring the clues when recognizing prior knowledge that relates to common tangent lines of two circles in the form of follow-up questions. They tend not to specify the information in the problem by themselves. This is in line with the Guild and Garger theory (in Raven, 1992) regarding the character of FI students, i.e., receiving information in general. The differences occur when connecting prior knowledge to given new tasks. SD-1 and SD-2 succeeded in recognizing, building-with, and constructing completely new knowledge than SD-3 and SD-4. They were hampered by the images and symbols they made themselves. Additionally, SD-2 tend to elaborate information that matters relating to the previous knowledge. They form new knowledge, connect it, and successfully construct new knowledge. This difference is possible because of the influence of experience and knowledge possessed by each subject. Even though they have a similar cognitive style, the maturity of knowledge and experience possessed by 
different individuals allows the differences in processing the same information. In addition, this difference can arise due to environmental influences faced by the subjects. This is in accordance with Witkin and Goodenough's theory (in Danili \& Reid, 2006) which state that FI individuals tend to have difficulty separating themselves from the environment they receive.

In addition, four FI subjects tend to be the same in the process of abstractions. They can directly detail concepts relating to prior knowledge to form new knowledge, tend not to require guidance to process the information received themselves, and make a classification of knowledge that they construct. This is in line with the theory of Guild and Garger (in Raven, 1992) regarding the character of FI students, i.e., tend to receive information analytically, able to develop structures and organize their own information received, and can make differences in concepts more specifically. The differences arise when subjects have a different focus of knowledge used. SI-1 focused on what he saw in the given task and tried to find the knowledge that can be used in relation to the given task, whereas SI-2, SI-3, and SI-4 beside focused on what they saw also consider the relevant prior knowledge and closely related to the task given. However, this difference makes SI-1 unable to construct new knowledge. This may be influenced by the knowledge that is not yet strongly embedded. Therefore, SI-1 is in a difficult way in associating the knowledge to the new situations given.

Based on the abstraction of FD and FI students in constructing a concept of common tangent lines of two circles, the fundamental difference that occurs in students with these two categories of cognitive style lies in recognizing action. The four FD subjects tend to recognize less prior knowledge since they only looked at the outcome rather than FI subjects who had been able to consider previous knowledge that was not visible but had an impact on the next activities. Whereas in building-with activities, all eight subjects tend to do the same activity that is reusing relevant knowledge to complete tasks. FD students tend to do recognizing, building-with, and construction activities by requiring direction in the form of questions and more time to find ideas. Thus, they can gather the prior knowledge relevant to new situations given, link knowledge used as a reference for completing assignments and identify the characteristics of the knowledge he acquired to form a complete concept. FI students tend to do recognizing, buildingwith, and construction activities by themselves. They can directly gather some knowledge related to new situations based on their experiences, relate them to new situations, then identify characteristics in each case of knowledge that was built before based on special characteristics that distinguish it from other. However, there may be FI students in the process of constructing new knowledge who need more guidance. The emergence of assistance needed by FI and FD students can be explained by the notions of Zone Proximal Development (ZPD) and scaffolding (Vygotsky, 1978; Fani \& Ghaemi, 2011). This theory is in the same manner to the conditions that occur in students with two different types of cognitive styles. There is a condition when the students can do it themselves and when they need help.

Despite the important findings of the present study which contribute to the understanding of FI and FD students in abstraction, this study did not examine the causes of the emergence of differences in FD and FI students as well as each student in the same cognitive style category. For this reason, further researches can explore the causes of the emergence of differences as the influence of cognitive styles on students' abstraction processes. 


\section{Conclusion}

Field-dependent and field-independent students tend to do the same abstraction process on building-with activities but differ on recognizing and construction activities in learning common tangent lines of two circles. Students with field-dependent cognitive style tend to be affected by their learning environment, for example, the context in which students learn. They need more help in organizing information, for instance, recognizing their prior knowledge which is relevant to the task. Meanwhile, field-independent students tend to be able to organize their own information. There is a case where FI students need help in completing the tasks, that is when the problem being faced has a higher level of difficulty that requires prior analysis to be able to recognize relevant prior knowledge. This finding implies that mathematics teachers need to understand each students' cognitive style for consideration in designing effective learning activities. For instance, giving tasks that allow students to form their own mathematical concepts and bringing up discussion activities between groups based on cognitive styles. In addition, the teachers can accustom students to work by recognizing their prior knowledge relevant to the problem given and connecting them to construct new knowledge.

\section{References}

Agnesya, M. (2015). Analisis kemampuan abstraksi siswa dalam menyelesaikan soal materi pokok segitiga (Master Thesis). Retrieved from http://repo.iain-tulungagung.ac.id/1692.

Alamolhodaei, H. (2001). Convergent/Divergent cognitive styles and mathematical problem solving. Journal of Science and Mathematics Education in Southeast Asia, 24(2), 102-117.

Bostic, J. Q. (1988). Cognitif styles: Their consolidation and relationship beyond cognitive developmental level and critical thinking ability to understanding science. Texas: Tech University.

Celebioglu, B., \& Yazgan, Y. (2015). The investigation OF fourth graders' construction process OF fractional multiplication using RBC $+\mathrm{C}$ model. Procedia social and behavioral sciences, 197, 316319. Doi: $10.1016 /$ j.sbspro.2015.07.143

Chrysostomou, M., Pitta-Pantazi, D., Tsingi, C., Cleanthous, E., \& Christou, C. (2013). Cognitive styles and their relation to number sense and algebraic reasoning. Educational Studies in Mathematics, 83(2), 205-223. Doi:10.1007/s10649-012-9448-0

Danili, E., \& Reid, N. (2006). Cognitive factors that can potentially affect pupils' test performance. Chemistry education research and practice, 7(2), 64-83. Doi:10.1039/B5RP90016F

Dreyfus, T.(2007). Editorial: Review Articles. Educational Studies in Mathematics, 66(1). Doi:10.1007/s10649-007-9095-z

Dreyfus, T., Hershkowitz, R.,\& Schwarz, B. (2015). The nested epistemic actions model for abstraction in context: Theory as methodological tool and methodological tool as theory. In A. Bikner-Ahsbahs, C. Knipping, \&N. Presmeg (Eds.), Approaches to Qualitative Research in Mathematics Education (pp. 185-217). Advances in mathmatics education. Dordrecht: Springer. Doi:10.1007/978-94-0179181-6 8

Fani, T., \& Ghaemi, F. (2011). Implications of Vygotsky's zone of proximal development (ZPD) in teacher education: ZPTD and self-scaffolding. Procedia social and behavioral science, 29(2011), 1549-1554. Doi:10.1016/j.sbspro.2011.11.396

Ferrari, P.L. (2003). Abstraction in mathematics. Philosophical Transactions of the Royal Society of London: Biological Science, 358(1435), 1225-1230. Doi:10.1098/rstb.2003.1316

Gal, H., \& Linchevski, L. (2010). To see or not to see: Analyzing difficulties in geometry from the perspective of visual perception. Educational Studies in Mathematics, 74(2), 163-183. Doi:10.1007/s10649-010-9232-y 
Hassan, I., \& Mitchelmore, M. (2006, July). The role of abstraction in learning about rates of change. Paper presented at the Mathematics Education Research Group of Australasia Conference (29th : 2006). Retrieved from http://hdl.handle.net/1959.14/99690

Hershkowitz, R., Schwarz, B., \& Dreyfus, T. (2001). Abstraction in context: Epistemic actions. Journal for Research in Mathematics Education, 32(2), 195-222. Doi:10.2307/749673

Hershkowitz, R., Dreyfus, T., Ben-Zvi, D., Friedlander, A., Hadas, N., Resnick, T., \& Schwarz, B. (2002). Mathematics curriculum development for computerized environments: A designer-research-teacherlearner activity. In L. D. English (Ed.), Handbook of International Research in Mathematics Education (pp. 657-694). New Jersey: Lawrence Erlbaum Associates.

Hershkowitz, R., Hadas, N., Dreyfus, T., \& Schwarz, B. (2007). Abstracting processes, from individual's constructing of knowledge to a group's "shared knowledge". Mathematics Education Research Journal, 19(2), 41-68. Doi:10.1007/BF03217455

Hong, J.Y., \& Kim, M.K. (2015). Mathematical abstraction in the solving of ill-structured problems by elementary school students in korea. Eurasia Journal of Mathematics, Science \& Technology Education, 12(2), 267-281. Doi:10.12973/eurasia.2016.1204a

Katranci, Y., \& Altun, M. (2013). The process of constructing the absolute value function knowledge for high school students. International Journal on New Trends in Education and Their Implications, 4(4), $1-13$.

Marashi, H., \& Moghadam, M. (2014). The difference between field-dependent and field-independent EFL learners' critical thinking and use of oral communication strategies. International Journal of Language Learning and Applied Linguistics World, 7(3), 434-458.

Mayer, R. E., \& Massa, L. J. (2003). Three facets of visual and verbal learners: Cognitive ability, cognitive style and learning preference. Journal of educational psychology, 95, 833-846. Doi:10.1037/00220663.95.4.833

Memnun, D. S.,Aydin, B., Ozbilen, O., \& Erdogan, G. (2017). The abstraction process of limit knowledge. Education sciences theory \& practice, 17(2), 345-371. Doi:10.12738/estp.2017.2.0404

Moleong, Lexy J. (2007). Metodologi penelitian kualitatif. Bandung: PT Remaja Rosda Karya.

Mutia. (2017). Analisis kesulitan siswa smp dalam memahami konsep kubus balok dan alternatif pemecahannya. Beta jurnal tadris matematika, 10(1), 83-102. Doi:10.20414/BETAJTM.V10I1.107

NCTM. (2000). Principles and standards for school mathematics. Reston, VA: NCTM

Nurafni, N., Miatun, A., \& Khusna, H. (2018). Profil pemahaman konsep teorema phytagoras siswa berdasarkan perbedaan gaya kognitif field independent dan field dependent. Kalamatika, 3(2), 175192. Doi:10.22236/KALAMATIKA.vol3no2.2018pp175-192

Nurhasanah, F., Kusumah, Y. S., \& Sabandar, J. (2013). Abstraction Process in learning geometry using GSP. Proceeding of 6th east asia regional conference on mathematics education, 4, 422-431. Doi:10.13140/2.1.1452.0005

Onwumere, O., \& Reid, N. (2014). Field dependency and performance in mathematics. European journal of education research, 3(1), 43-57. Doi:10.12973/eu-jer.3.1.43

Pitta-Pantazi, D., \& Christou, C. (2009). Cognitive styles, dynamic geometry and measurement performance. Educational Studies in Mathematics, 70(1), 5-26. Doi:10.1007/s10649-008-9139-z

Raven, M. (1992). Teaching student with different learning styles. The Agricultural Education Magazine, $65(3), 5-15$.

Shadiq, F. (2009). Model-model pembelajaran matematika SMP. Yogyakarta: PPPPTK Matematika.

Soedjadi, R. (2000). Kiat pendidikan matematika di Indonesia. Jakarta: Dirjen DIKTI.

Sugiyono. (2015). Metode penelitian pendidikan pendekatan kuantitatif kualitatif dan $R \& D$. Bandung: Alfabeta.

Susanto, H.A. (2008). Mahasiswa field independent dan field dependent dalam memahami konsep grup. Proceeding seminar nasional matematika dan pendidikan matematika. Yogyakarta: Universitas Negeri Yohyakarta.

Tinajero, C., \& Paramo, M. F. (1998). Field dependence-independence cognitive style and academic achievement: A review of research and theory. European Journal of Psychology of Education, 13(2), 227-251. Doi:10.1007/BF03173091

Tsamir, P., \& Dreyfus, T. (2002). Comparing infinite sets - A process of abstraction the case of ben. Journal of mathematical behavior, 21(1), 1-24. Doi:10.1016/S0732-3123(02)00100-1

Vygotsky, L.S. (1978). Mind in society. Cambridge, MA: Harvard University Press. 
Witkin, H. A., Moore, C. A., Goodenough, D. R., \& Cox, P. W. (1977). Field-dependent and fieldindependent cognitive styles and their educational implications. Review of educational research, 47(1), 1-64. Doi:10.2307/1169967

Yuen, C. L. (2015). Multitasking and learning in virtual environments (Master Thesis). Retrieved from https://era.library.ualberta.ca/Yuen_Connie_L_201508_MEd.pdf 